\title{
Association between preference for sweet foods and dental caries
}

\author{
Associação entre preferência por alimentos doces e cárie dentária
}

Adriana CAGNANI ${ }^{1}$

Andréia Moreira de Souza BARROS ${ }^{1}$

Luciana Luz Araújo de SOUSA ${ }^{1}$

Arlete Maria Gomes OLIVEIRA'

Luciane Zanin'

Flávia Martão FLÓRIO'

\section{ABSTRACT}

\section{Objective}

To assess the relationship between caries prevalence and sugar preference in schoolchildren.

\section{Methods}

The sample has consisted of 96 schoolchildren of both genders and age ranging from 5 to 12, enrolled at the Maria Aparecida de Jesus Segura Rural School in Sumaré, São Paulo, Brazil. The inclusions criteria were: enrolled schoolchildren; with an authorization to participate in the research, from the parents or guardians; cooperative and not having orthodontic appliances, difficulty with mouth opening and no restriction on sugar consumption. The history of caries was performed by calibrated examiners (Kappa=0,85) according the World Health Organization criteria. The preference for sugar was assessed using a modified version of the Sweet Preference Inventory. Each schoolchild tasted five grape juice solutions, in which the sugar concentration varied from 0 to $40 \mathrm{~g} /$ liter. The association between the variables, DMFT and dmft was dichotomized into $D M F T=0$ and $D M F T \geq 1 ; d m f t=0$ e dmft $\geq 1$ and the sugar preference as low $(A, B, C, D)$ and high $(E)$.

\section{Results}

There was no significant association between the genders as regards preference for sugar in the solutions (Fisher Exact Test, $p=0.2150$ ), and as regards the DMFT (Chi-Square Test, $p=0.2789$ ). In both caries history situations, the majority of the children preferred a high sugar concentration (Chi-Square Test, $p=0.2463$ ).

\section{Conclusion}

There were no association between history of caries and preference of sugar. There no was association between gender and preference for sugar.

Indexing terms: Dental caries. Epidemiology. Food preferences. Sucrose.

\section{RESUMO}

\section{Objetivo}

Avaliar a relação entre prevalência de cárie e preferência por açúcar em escolares.

\section{Métodos}

A amostra foi de 96 escolares, de ambos os gêneros e faixa etária de 5 a 12 anos de idade, matriculados na Escola Municipal Maria Aparecida de Jesus Segura do assentamento rural II de Sumaré, São Paulo. Os critérios de inclusão foram escolares matriculados com autorização para a pesquisa do responsável, cooperativos e que não apresentavam aparelho ortodôntico fixo, dificuldade de abertura bucal ou não restricão ao consumo de açúcar. A história de cárie foi realizada por examinadores calibrados (Kappa=0,85) segundo a Organização Mundial de Saúde. A preferência por açúcar foi verificada pelo teste Sweet Preference Inventory modificado. Cada escolar provou 5 soluções de suco de uva, cuja concentração de açúcar variou de 0 a $40 \mathrm{~g} /$ litro. A associação entre as variáveis, os índices CPOD e ceod foram dicotomizados em CPO=0 e $C P O \geq 1$; ceod=0 e ceod $\geq 1$ e a preferência por açúcar em baixa (A, B, C, D) e alta (E).

\section{Resultados}

Não houve associacão significante entre os gêneros em relacão à preferência por acúcar nas solucões de suco (Teste Exato de Fischer, p= 0,2150 ), e em relação ao CPO-D (teste Qui-quadrado, $\mathrm{p}=0,2789$ ). Para ambas as situações de história de cárie, a preferência da maioria das crianças foi por alta concentração de açúcar (teste Qui-quadrado, $p=0,2463$ ).

Conclusão

Não foi verificada a associação entre a história de cárie e preferência por açúcar. Não houve associação entre gênero e a preferência por açúcar.

Termos de indexação: Cárie dentária. Epidemiologia. Preferências alimentares. Sacarose.

\footnotetext{
${ }^{1}$ Faculdade São Leopoldo Mandic, Curso de Odontologia, Programa de Pós-Graduação em Odontologia Social. Rua José Rocha Junqueira, 13, Swift, 13045-755, Campinas, SP, Brasil. Correspondência para / Correspondence to: A CAGNANI. E-mail: <adrianacagnani@yahoo.com.br>.
} 


\section{INTRODUCTION}

Dental caries is an infectious-contagious disease, of a multifactorial nature resulting from the interaction of physical-chemical, biologic (saliva and teeth), behavioral (dietary habits, oral hygiene, lifestyle) and modulating factors (general health, socio-economic and educational levels) $)^{1-2}$.

Caries lesions have accompanied the human being since prehistoric times, an epoch in which the disease was characterized as being of low population impact in quantitative terms and severity ${ }^{2}$. Concomitant with the process of "civilization", an increase could be observed in the prevalence of the disease as a result of reduction in the consumption of complex carbohydrates and fibers and the introduction of a diet richer in fats, sugars and refined foods ${ }^{3}$. Thus, up to today, dental caries has been considered a serious public health problem².

A balanced diet capable of providing an adequate nutritional status has certainly contributed to a desirable oral condition in an individual. Therefore, some dietary restrictions, or even the excess ingestion of some specific dietary components, may influence the processes of odontogenesis (dental formation), eruption and the development of caries disease ${ }^{4}$.

Dental caries is one of the diseases with the highest incidence in childhood and the hosts diet may be seen as a primary factor in determining susceptibility to the disease ${ }^{5}$. A study of the nutritional status of the Brazilian population indicates that children belonging to the rural stratum present a more unfavorable nutritional situation than those in the urban stratum, as a result of poorer living conditions ${ }^{6}$. Cross sectional studies conducted in various countries in the world have demonstrated that residing in rural areas is a predictive factor for the development of dental caries in childhood ${ }^{7-9}$.

The consumption of sweetened foods is influenced by a variety of biological, psychological, social and environmental factors. It has been suggested that there is a preference for sweets in populations with worse socioeconomic conditions ${ }^{10}$. Knowing the cariogenic power of fermentable carbohydrates, especially sugar, it makes it necessary to know the dietary habits of the population, in order to develop public policies, adopt efficient preventive methods, in addition to encouraging changes towards developing healthier habits ${ }^{11}$. Therefore, the aim of this study was to evaluate the preference for sugar and its association with the prevalence of caries in schoolchildren from 05 to 12 years of age at a municipal school in Sumaré (SP).

\section{METHODS}

\section{Ethical aspects}

This study was conducted in accordance with the precepts determined by resolution 196/96 of 10/10/96 of the National Health Council of the Ministry of Health, and approved by the Research Ethics Committee of the São Leopold Mandic School of Dentistry, Protocol Number 2010/0324.

\section{Study population}

The population of this study was 128 schoolchildren from 5 to 12 years of age, of both genders, enrolled at "Escola Municipal de Ensino Fundamental Rural Maria Aparecida de Jesus Segura" of the rural settlement II in the municipality of Sumaré-SP. The participants in this study were 96 schoolchildren of both genders $(n=96)$, who presented the Term of Free and Informed Consent (TFIC) signed by the persons legally responsible for them. Volunteers who used fixed orthodontic appliances, presented difficulty in opening the mouth at the time of the exam, and reported a restriction on sugar consumption were excluded from the study. A pilot study was conducted with the researchers involved in the survey, to evaluate the degree of the children's discernment as regards the flavor of grape juice solutions with different concentrations of sugar.

\section{Calibration}

The calibration process began with a theoretical stage of four hours duration, which consisted of presentation of the criteria of the DMFS and dmf (decayed, missing, filled surfaces in permanent and primary dentition ${ }^{12}$. Each type of criterion was presented by means of slides for the purposes of learning and discussion. After this, the chart that was used was presented, and the clinical exam routine was explained. Later a practical stage was conducted, with a clinical exam performed in 12 volunteers. The diagnostic reproducibility of the examiners was evaluated by Kappa Statistics, and in cases in which an agreement lower than $85 \%$ was observed, further training was implemented. To verify the oral health conditions, the DMFS and dmft indices were used, which evaluate the total number of decayed, missing and filled teeth for permanent and primary dentition, respectively, in accordance with 
the methodology recommended by the World Health Organization ${ }^{13}$. The data were collected and noted on the clinical chart prepared by the researchers themselves.

\section{Test of preference for sugar}

The test of preference for sugar was prepared in accordance with a modified version of the "Sweet Preference Inventory". For this test, sweetened grape juice products always of the same commercial brand were used, respecting the proportion determined by the manufacturer (1 portion of concentrated juice to 2 portions of water). The following five sucrose concentrations were used:

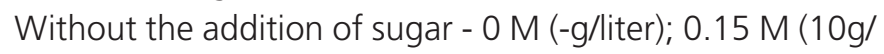

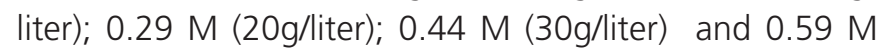
(40g/liter). To perform the test, after going through the clinical evaluation (survey of DMFS and dmft indices), each child received the juice in small disposable cups (containing $10 \mathrm{ml})$, at ambient temperature, in sequence by letters $A$, $B, C, D, E$, with cup marked with letter $A$ being without the addition of sugar and the one with letter $E$ that with the highest concentration of sugar. To "neutralize" the palate before all the tasting tests, the children ate a piece of "cream cracker" type of biscuit. Between one tasting test and the other, the child was asked which solution he/she preferred, and at the end of the test, the child pointed out the solution of his/her choice, which was noted on the child's chart. The sample was dichotomized as low preference for sugar (Solutions A, B, C, D) and high preference (Solution E). The participants who present urgent treatment needs were duly referred for dental treatment at the São Leopoldo Mandic School of Dentistry clinic, Campinas (SP).

The data were analyzed by the Chi-Square and Fisher Exact tests with the use of the BioEstat software program.

\section{RESULTS}

After data collection, it was observed that the solution with the highest sugar concentration (E) was the one preferred by the majority of the volunteers both of the male $(n=36)$ and female $(n=29)$ gender, however there was no association between gender and preference for sugar in the grape juice solutions, according to Table 1.

When associating gender and caries history, there was no statistically significant association, according to Table 2 .
Table 1. Distribution of sample according to gender and grape juice solutions.

\begin{tabular}{|c|c|c|c|c|c|c|c|c|c|c|}
\hline \multicolumn{11}{|c|}{ Preference for sugar (Molar = g/liter) } \\
\hline & \multicolumn{2}{|c|}{$\begin{array}{c}\mathrm{A} \\
0 \mathrm{M}\end{array}$} & \multicolumn{2}{|c|}{$\begin{array}{c}\mathrm{B} \\
0.15 \mathrm{M}= \\
10 \mathrm{~g} / \mathrm{liter}\end{array}$} & \multicolumn{2}{|c|}{$\begin{array}{c}\mathrm{C} \\
0.29 \mathrm{M}= \\
20 \mathrm{~g} / \mathrm{liter}\end{array}$} & \multicolumn{2}{|c|}{$\begin{array}{c}D \\
0.44 \mathrm{M}=30 \mathrm{~g} / \\
\text { liter }\end{array}$} & \multicolumn{2}{|c|}{$\begin{array}{c}E \\
0.59 M=40 \mathrm{~g} / \\
\text { liter }\end{array}$} \\
\hline Gender & $n$ & $\%$ & $n$ & $\%$ & $n$ & $\%$ & $n$ & $\%$ & $n$ & $\%$ \\
\hline Male & 0 & 0.0 & 2 & 100.0 & 4 & 50.0 & 7 & 35.0 & 36 & 55.4 \\
\hline Female & 1 & 100.0 & 0 & 0.0 & 4 & 50.0 & 13 & 65.0 & 29 & 44.6 \\
\hline Total & 1 & 100.0 & 2 & 100.0 & 8 & 100.0 & 20 & 100.0 & 65 & 100.0 \\
\hline
\end{tabular}

Note: Exact Fischer Test: $p=0.2150$.

Table 2. Distribution of sample according to gender and caries history.

\begin{tabular}{|c|c|c|c|c|}
\hline \multicolumn{5}{|c|}{ Caries history } \\
\hline \multirow[b]{2}{*}{ Gender } & \multicolumn{2}{|c|}{$\begin{array}{c}\text { Absent } \\
\text { DMFS and dmf =0) }\end{array}$} & \multicolumn{2}{|c|}{$\begin{array}{c}\text { Present } \\
\text { DMFS or } \mathrm{dmf} \geq 1 \text { ) }\end{array}$} \\
\hline & $n$ & $\%$ & $n$ & $\%$ \\
\hline Male & 13 & 59.1 & 34 & 46.0 \\
\hline Female & 9 & 40.9 & 40 & 54.0 \\
\hline Total & 22 & 100.0 & 74 & 100.0 \\
\hline
\end{tabular}

Note: Chi-square Test: $p=0.2789$.

Figure 1 illustrates the analysis between the association with low preference for sugar (A, B, C, D) and high preference $(E)$ in the sample dichotomized for presence or absence of caries. For both caries history situations, the preference of the majority of the children was for high sugar concentration (history of absence of caries $(n=21)$ and history of caries presence $(n=64)$, without statistically significant association between the variables.

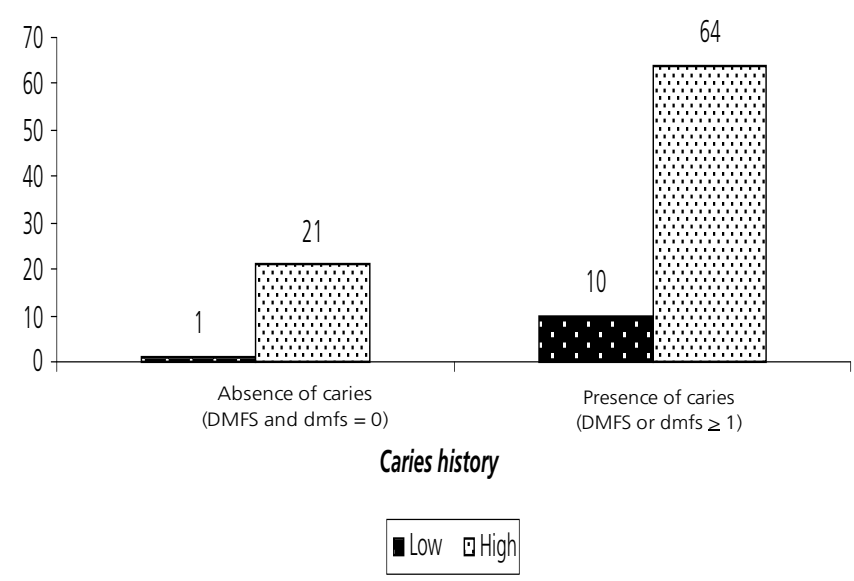

Figure 1. Distribution of sample according to caries history and low or high preference for sugar.

Note: Chi-square Test: $p=0.2463$ 


\section{DISCUSSION}

According to the International Sugar Organization ${ }^{14}$, the quantity of sucrose consumed in the Brazilian diet is $55 \mathrm{~kg} /$ person/year. The use of sugar in the Brazilian diet increased significantly over the last few decades. The mean consumption of this carbohydrate in the 1930 s was 15 kilos/inhabitant/year, and rose to kilos/ inhabitant/year in 1950, 40 kilos/inhabitant/year in 1950 and 50 kilos/inhabitant/year in 1990. At world level, Brazil consumes less only than India and the countries of the European Union ${ }^{15}$. According to the Family Budget Survey 2008-2009, the mean daily intake of total sugars underwent great variation between the age ranges, being higher in the group of adolescents of both sexes, ranging from $105.4 \mathrm{~g}$ to $113.1 \mathrm{~g}$ among boys and $106.8 \mathrm{~g}$ to 110.7 $\mathrm{g}$ among girls. In individuals of 60 years or older presented the lowest mean total sugar consumption. The mean daily total sugar consumption among adolescents was around $30 \%$ higher than it was among the elderly, being $15 \%$ to $18 \%$ higher among adults ${ }^{16}$.

In this study, the solution with the highest concentration of sugar ( $E$ ) was the one preferred by the majority of the volunteers, irrespective of gender, a result differing from the findings of Honkala et al. ${ }^{17}$ and Nilsson \& Holm ${ }^{18}$.

The taste pattern of preference for sweeter solutions, and consequently, higher sugar consumption has been related in the literature to higher levels of caries $^{10,19}$. However, in this study, this association could not be observed.

In addition, no statistically significant differences were observed with regard to the caries index in relation to gender, in agreement with the findings of Amaral et al. ${ }^{20}$ and Barbosa et al. ${ }^{21}$.

The relationship between sugar consumption and dental caries is difficult to quantify, due to inherent limitations, such as the duration of exposure of the teeth to sugars affected by the variability of the patterns of consumption, prevalence of caries, influenced by diverse factors that are difficult to control, including the mineral content in the diet (fluoride, calcium, phosphorous), health care, oral hygiene habits and educational level ${ }^{22}$.

Although the majority of volunteers in this study opted for the sweeter juice (Juice E), no statistically significant association was observed between caries history and preference for sweeter substances, in agreement with the study of Brandão et al. ${ }^{23}$. In disagreement, however, with Neumann et al. ${ }^{24}$, who found a positive correlation. Nevertheless, a further investigation is suggested with regard to the consumption of fermentable carbohydrates and caries experience in this population, in order to seek new data related to behavioral and biologic factors involved in the process of dental caries disease formation.

The literature has shown a moderate relationship between sucrose intake and the increase in caries prevalence in the population 7,25 . According to Hoffmann et al. ${ }^{26}$, in 2002 in the city of Campinas (SP), the DMFS was 1.34 and the $\mathrm{dmft}=1.68$. In this study, the dental caries prevalence found in primary dentition was 3.16 and the DMFS 0.60.

Understanding dental caries as a multifactorial disease, the biologic, social and behavioral factors appear to be frequently associated with dental caries, and have shown to be easier to understand when the risk factors for this disease are studied ${ }^{27}$.

The relationship between sugar consumption and caries is much weaker in the modern era, due to the exposure to fluoride, than it used to be in pervious epochs. Controlling sugar consumption continues to be an important part in caries prevention, however, it is not the most relevant aspect ${ }^{28}$.

\section{CONCLUSION}

The majority of the volunteers preferred the sweeter solutions. There was no statistically significant association between caries prevalence and the preference for sugar. No association was observed between gender and preference for sugar.

\section{Collaborators}

A CAGNANI, AMS BARROS and LLA SOUSA cooperated with the bibliographical research, data collection and analysis and writing the article. AMG OLIVEIRA was responsible for the field research and participated in data collection and writing the article. LZ SOUZA participated in data collection and analysis and in writing the article. FM FLÓRIO guided the research, cooperated with data collection and writing the article. 


\section{REFERENCES}

1. Lima JEO. Cárie dentária: um novo conceito. Rev Dent Press Ortodon Ortop Facial. 2007;12(6):119-30. doi: 10.1590/S141554192007000600012.

2. Gomes D, Da Ros MA. A etiologia da cárie no estilo de pensamento da ciência odontológica. Ciênc Saúde Coletiva. 2008;13(3):108190. doi: 10.1590/S1413-81232008000300031.

3. Batista LRV, Moreira EAM, Corso ACT. Alimentação, estado nutricional e condição bucal da criança. Rev Nutr. 2007;20(2):191-6. doi: 10.1590/S1415-52732007000200008.

4. Moynihan P. J. The role of diet and nutrition in the etiology and prevention of oral diseases. Bull World Health Organ. 2005;83(9):694-9.

5. Tomita NE, Bijella VT, Lopes ES, Franco LJ. Prevalência de cárie dentária em crianças da faixa etária de 0 a 6 anos matriculados em creches: importância de fatores sócio-econômicos. Rev Saúde Pública. 1996;30(5):413-20. doi: 10.1590/S003489101996000500003.

6. Veiga VG, Burlandy L. Indicadores sócio-econômicos, demográficos e estado nutricional de crianças e adolescentes residentes em um assentamento rural do Rio de Janeiro. Cad Saúde Pública. 2001;17(6):1465-72.

7. Mattila ML, Rautava P, Sillanpaa M, Paunio P. Caries in five-year-old children and associations with family-related factors. J Dent Res 2000;79(3):875-81. doi: 10.1177/00220345000790031501.

8. Vargas CM, Monajemy N, Khurana P, Tinanoff N. Oral health status of preschool children attending Head Start in Maryland, 2000. Pediatr Dent. 2002;24(3):257-63.

9. Tsai Al, Chen C-Y, Li L-A, Hsiang C-L, Hsu R-K. Risk indicators for early childhood caries in Taiwan. Community Dent Oral Epidemiol. 2006;34(6):437-45. doi: 10.1111/j.1600-0528.2006.00293.x.

10. Jamel HA, Sheiham A, Cowell CR, Watt RG. Taste preference for sweetness in urban and rural population in Iraq. J Dent Res. 1996;75():1879-84. doi: 10.1177/00220345960750111001.

11. Chaves AMB, Rosenblatt A, Colares V. A importância da dieta do desmame na saúde oral. J Bras Odontopediatr Odontol Bebê. 2003;6(30):158-62.

12. World Health Organization. Oral health surveys: basic methods. 4th ed. Geneva: World Health Organization; 1997 [cited 2012 Set 10]. Available from: <http://www.paho.org/hq/ dmdocuments/2009/OH_st_Esurv.pdf $>$.

13. Organização Mundial da Saúde. Levantamentos básicos em saúde bucal. $4^{a}$ ed. São Paulo: Santos; 1999 [citado 2012 Set 10]. Disponível em: <http://www.paho.org/hq/dmdocuments/2009/ OH_st_Esurv.pdf>.

14. International Sugar Organization. World per capita consumption of centrifugal sugar. London: International Organization for Standardization; 1999.

15. Brasil. Ministério da Agricultura, Pecuária e Abastecimento. Balanço nacional de cana-de-açúcar e agroenergia / Ministério da Agricultura, Pecuária e Abastecimento. Brasília: MAPA / SPAE; 2007 [citado 2012 Set 15]. Disponível em: < http://www. agricultura.gov.br/arq_editor/file/Desenvolvimento_Sustentavel/ Agroenergia/estatisticas/PDF\% 20-\%20BALANO \% 20 NACIONAL_0_0_0.pdf>.
16. Brasil. Instituto Brasileiro de Geografia e Estatística. Pesquisa de orçamentos familiares 2008-2009: análise do consumo alimentar pessoal no Brasil. Rio de Janeiro: Instituto Brasileiro de Geografia e Estatística; 2011 [citado 2012 Set 15]. Disponível em: <http:// www.ibge.gov.br/home/estatistica/populacao/condicaodevida/ pof/2008_2009_analise_consumo/pofanalise_2008_2009. $\mathrm{pdf}>$.

17. Honkala E, Nyyssönen $V$, Rimpelä A. Determinants of frequency of children's sweets consumption. Acta Odontol Pediatr. 1984;5(1):13-9.

18. Nilsson B, Holm AR. Taste thresholds, taste preference, and dental caries in 15-years-olds. J Dent Res. 1983;62:1069-72.

19. Petti S, Tarsitani G, Panfili P, Simonetti D, Arca A. Oral hygiene, sucrose consumption and dental caries prevalence in adolescent systemic fluoride non-users. Community Dent Oral Epidemiol. 1997;25(4):334-6. doi: 10.1111/j.1600-0528.1997.tb00950.x.

20. Amaral RC, Hoffmann RHS, Cypriano S, Sousa MLR, Silva AAZ. Prevalência de cárie e necessidades de tratamento em préescolares e escolares de Rafard - SP - Brasil. Cienc Odontol Bras. 2006;9(3):87-93.

21. Barbosa APMB, Kriger L, Moysés ST, Moysés SJ. Prevalência da doença cárie em crianças de cinco anos de idade na cidade de Curitiba: análise crítica. Epidemiol Serv Saúde. 2007;16(2):1425.

22. König KG, Navia J. Nutritional role of sugars in oral health. Am J Clin Nutr. 1995;62(1):275S-83S.

23. Brandão IMG, Arcieri RM, Sundefeld MLM, Moimaz SAS. Cárie precoce: influência de variáveis sócio-comportamentais e do lócus de controle da saúde em um grupo de crianças de Araraquara, São Paulo, Brasil. Cad Saúde Pública. 2006;22(6):1247-56. doi: 0.1590/S0102-311X2006000600014.

24. Neumann SRB, Freitas SFT, Lacerda JT. Prevalência de cárie e fatores associados na Dentição decídua em escolares de sete anos de idade da rede pública de Joinville, SC, Brasil. Pesq Bras Odontoped Clin Integr. 2010;10(3):405-11.

25. Rodrigues CS, Watt RG, Sheiham A. Effects of dietary guidelines on sugar intake and dental caries in 3-yearolds attending nurseries in Brazil. Health Promotion Internat. 1999:14(4):32935. doi: 10.1093/heapro/14.4.329.

26. Hoffmann RHS, Cypriano S, Souza MLR, Wada RS, Murakami L, Abdalla NMM. Campinas: a tendência da cárie dentária em três períodos no tempo: 1961-1976; 1976-1992; 1992-2002. Arq Odontol. 2005;41(4):273-368.

27. Anderson CA, Curzon ME, van Loveren C, Tatsi C, Duggal MS. Sucrose and dental caries: a review of the evidence. Obes Rev. 2009;10(Suppl 1):41-54. doi: 10.1111/j.1467789X.2008.00564.x.

28. Burt BA, Pai S. Sugar consumption and caries risk: a systematic review. J Dent Educ. 2001;65(10):1017-23.

Received on: 1/10/2012 Final version resubmitted on: 31/1/2013 Approved on: 21/5/2013 
